\title{
Pozzolanic Properties of Micronized Biomass Silica in Enhancing Compressive Strength and Water Permeability of Concrete
}

\author{
Suraya Hani Adnan ${ }^{1}$, Ismail Abdul Rahman ${ }^{2}$, Hamidah Mohd Saman ${ }^{3} \&$ Fetra Venny Riza ${ }^{2}$ \\ ${ }^{1}$ Faculty of Technology Engineering, Universiti Tun Hussein Onn Malaysia (UTHM), Malaysia \\ ${ }^{2}$ Faculty of Civil and Environmental Engineering, Universiti Tun Hussein Onn Malaysia (UTHM), Malaysia \\ ${ }^{3}$ Faculty of Civil Engineering, Universiti Teknologi Mara (UiTM), Malaysia \\ Correspondence: Suraya Hani Adnan, Faculty of Technology Engineering, Universiti Tun Hussein Onn Malaysia \\ (UTHM), Malaysia. Tel: 60-7-456-4385. E-mail: suraya@uthm.edu.my
}

Received: August 9, 2012

Accepted: September 27, $2012 \quad$ Online Published: October 11, 2012

doi:10.5539/mas.v6n11p1

URL: http://dx.doi.org/10.5539/mas.v6n11p1

\begin{abstract}
This study presents the analysis and the benefits from using Micronized Biomass Silica (MBS) of rice husk which comprises of high content of silica. MBS was generated from controlled burning of the husk into off-white biomass silica ash and crushing the ash into micronized size. Concrete samples containing various percentages of MBS were tested for workability, compressive strength and also water permeability performances. It was found that the optimum percentage of MBS added to the concrete that lead to good performance of concrete in terms of compressive strength and water permeability was $12 \%$. The compressive strength increased up to $43 \%$ when $12 \%$ of MBS was added to the concrete after 90 days period. Increasing the content of MBS exceeding the optimum percentage showed inferior performance of the concrete. It indicates that the pozzolanic reaction properties of MBS could improve the compressive strength and water permeability of concrete.
\end{abstract}

Keywords: Micronised Biomass Silica, rice husk, compressive strength, water permeability

\section{Introduction}

Concrete is produced when cement, coarse aggregate, fine aggregate, water and admixtures are mixed thoroughly. Concrete is considered of good quality when it enables to achieve good strength and durability (Neville, 2004). Good strength is achieved when concrete can sustain maximum load imposed on it. To achieve good durability, the concrete should be able to attack from aggressive ion either externally or internally. One of the methods to produce quality concrete is by adding pozzolanic material. Pozzolanic material like fly ash, silica fume and ground granulated blastfurnace slag has been widely used in construction industry. The pozzolanic material is generally produced from by-product of wastes and thus, it has advantages in encouraging the application of waste product which is good for environmental conservation (Sampaio et al., 2000). Normally, these pozzolanic materials are functioning as cement replacement material which substitute a part of cement content. In this study, the Micronized Biomass Silica (MBS) was produced from the burning of rice husk was used as cement replacement in concrete samples. Various percentages of MBS were added to replace cement in order to determine the optimum percentage that gives the maximum performance of concrete produced. The performances considered in this paper are on the compressive strength and water permeability of the produced concrete.

\section{Micronized Biomass Silica (MBS)}

Biomass waste material used in the production of MBS was rice husks. The rice husk was taken from Bernas rice milling plant in Kedah, Malaysia. The husk was burnt under controlled in a rotary furnace at Material Laboratory of the Faculty of Civil and Environmental Engineering, UTHM (Lee et al., 2007). The husk fed was into the furnace in a continuous process through multiple distributed inlets at the furnace temperature regime of $500{ }^{\circ} \mathrm{C}$ to produce white amorphous biomass silica. This furnace is equipped with controlling opening for the air (oxygen) to come in and assist a complete burning process and thus produce low carbon content of white amorphous biomass silica ash. The perforated trays in the furnace rotated to enhance the mixing process, heat distribution and to achieve optimum burning efficiency. After one hour of burning, the white biomass silica ash falls through the perforated trays and into a collecting funnel at the downstream of the furnace. The 
characteristics of the burnt ash are as shown in Table 1. The pozzolanic ash is white in colour and the results from Table 1 indicate that an off-white colour of biomass silica was produced when the burning temperature was fixed at $500{ }^{\circ} \mathrm{C}$ with a weight loss $77.1 \%$ (the percentage of reduced mass from origin weight). For burning temperature below $450{ }^{\circ} \mathrm{C}$, the organic constituents of the biomass is still not decompose and for temperature above $550{ }^{\circ} \mathrm{C}$ the ash has less pozzolanic value.

The average diameter size of the biomass silica ash collected from the burning was about $48 \mu \mathrm{m}$. The collected ash was broken into smaller size in-order for the silica to act as micro structure filler in concrete. Jar Mill equipment which contains 50 balls mill was used for grinding the biomass silica ash into finer particles. The jar rotated for 60 minutes to produce an average of $25.77 \mu \mathrm{m}$ of biomass silica ash. The micronized ash used for this study is as shown in Figure 1. According to Neville (2004) increasing the fineness of the silica ash will make the ash to act effectively as micro structure filler.

Table 1. Characteristic ash burnt with various furnace temperatures (Lee et al., 2007)

\begin{tabular}{ccc}
\hline Furnace & \multicolumn{2}{c}{ Ash Production } \\
\cline { 2 - 3 } Temperature & Ash Colour & Percentage of Weight Loss \\
\hline $300{ }^{\circ} \mathrm{C}$ & Black & $29.8 \%$ \\
$400^{\circ} \mathrm{C}$ & Grey & $66.8 \%$ \\
$500{ }^{\circ} \mathrm{C}$ & Off-White & $77.1 \%$ \\
$600{ }^{\circ} \mathrm{C}$ & Grey & $74.7 \%$ \\
\hline
\end{tabular}

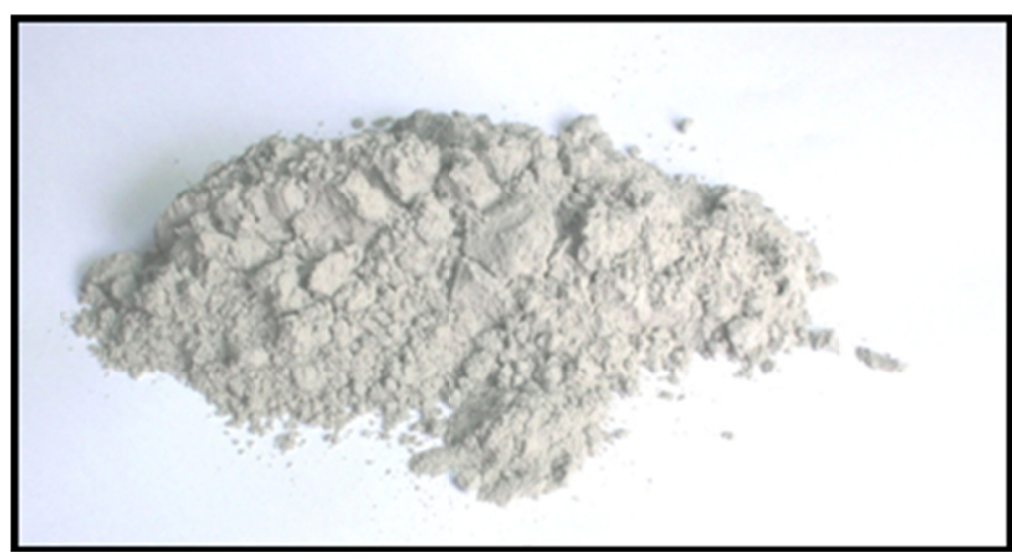

Figure 1. MBS of $25.77 \mu \mathrm{m}$ size

\subsection{Chemical Composition of $M B S$}

The chemical contents in MBS are as shown in Table 2. According to this table, the total percentage of main oxides for MBS which are $\mathrm{SiO}_{2}+\mathrm{Al}_{2} \mathrm{O}_{3}+\mathrm{Fe}_{2} \mathrm{O}_{3}$ is $88.544 \%$. This percentage fulfils the requirement for pozzolans material as stated by ASTM C 618-08a standard which specifies that the percentage must be more than $70 \%$. Thus, it indicates that the MBS used in this study has fulfilled the requirement as pozzolanic material. The standard also specified that $\mathrm{MgO}$ and $\mathrm{SO}_{3}$ contents should not exceed 5\% and both of the compounds had not exceeded the limit. On the other hand, is equal to 0.590 which the content is within the standard (not exceeding 5\%). Furthermore, loss on ignition (LOI) for MBS also follows the standard which specifies does not exceed 6\%. This indicates that the burning condition for producing MBS was appropriate because the results shown it comply with the standard. However, the content of $\mathrm{K}_{2} \mathrm{O}$ compound is quite high and according to Neville (2004), this chemical composition will have some effect on the strength development of concrete due to its reaction with aggregate. Based on chemical composition as in Table 2, the MBS it can be classified as Class F of Fly Ash according to ASTM C 618-08a standard. 
Table 2. Chemical properties of MBS

\begin{tabular}{cc}
\hline Properties & Value \\
\hline Surface Area & $24.4039 \mathrm{~m}^{2} / \mathrm{g}$ \\
Loss Of Ignition & 1.22 \\
\hline Chemical Composition (\%) & \\
\hline $\mathrm{SiO}_{2}$ & 87.67 \\
$\mathrm{Al}_{2} \mathrm{O}_{3}$ & 0.343 \\
$\mathrm{Fe}_{2} \mathrm{O}_{3}$ & 0.531 \\
$\mathrm{CaO}$ & 1.18 \\
$\mathrm{MgO}$ & 0.872 \\
$\mathrm{~K}_{2} \mathrm{O}$ & 5.078 \\
$\mathrm{SO}_{3}$ & 0.590 \\
\hline
\end{tabular}

The chemical composition contents of the MBS are compared with other established Supplementary Cementitious Materials (SCM) like RHA, silica fume, fly ash, palm oil fuel ash (POFA) and sawdust ash and are as shown in Table 3. It shows that the percentage of silica dioxide $\left(\mathrm{SiO}_{2}\right)$ of MBS is higher than normal RHA and second to silica fume. This indicates MBS is one of Supplementary Cementitious Materials.

Table 3. Chemical composition of MBS and other Supplementary Cementitious Materials (SCM)

\begin{tabular}{ccccccc}
\hline & \multicolumn{5}{c}{ Type of Ash } \\
\cline { 2 - 7 } $\begin{array}{c}\text { Chemical } \\
\text { Compositions }\end{array}$ & MBS (\%) & $\begin{array}{c}\text { RHA (\%) } \\
\text { (Isaia et } \\
\text { al., 2003) }\end{array}$ & $\begin{array}{c}\text { Silica Fume (\%) } \\
\text { (Toutanji \& } \\
\text { El-Korochi, } \\
1995)\end{array}$ & $\begin{array}{c}\text { Fly Ash (\%) } \\
\text { (Oner et al., } \\
\text { 2005) }\end{array}$ & $\begin{array}{c}\text { POFA (\%) } \\
\text { (Awal \& } \\
\text { Hussin, } \\
1997)\end{array}$ & $\begin{array}{c}\text { Sawdust (\%) } \\
\text { (Elinwa \& } \\
\text { Mahmood, } \\
2002)\end{array}$ \\
\hline $\mathrm{SiO}_{2}$ & 87.67 & 86.5 & 95.75 & 57.55 & 43.6 & 67.2 \\
$\mathrm{Al}_{2} \mathrm{O}_{3}$ & 0.343 & 0.3 & 0.35 & 25.16 & 11.4 & 4.09 \\
$\mathrm{Fe}_{2} \mathrm{O}_{3}$ & 0.531 & 0.1 & 0.21 & 6.5 & 4.7 & 2.26 \\
$\mathrm{CaO}$ & 1.18 & 0.5 & 0.17 & 2.1 & 8.4 & 9.98 \\
$\mathrm{MgO}$ & 0.872 & 0.3 & 0.09 & 2.5 & 4.8 & 5.8 \\
$\mathrm{~K}_{2} \mathrm{O}$ & 5.078 & 1.6 & - & 3.65 & 3.5 & 18.75 \\
$\mathrm{SO}_{3}$ & 0.59 & 0.1 & 0.42 & 0.19 & 2.8 & - \\
\hline Loss Of & 1.22 & 9.1 & 1.44 & 1.66 & 18 & 4.67 \\
Ignition & & & & & & \\
\hline
\end{tabular}

\section{Performance of Compressive Strength}

The pozzolanic reaction occurs when MBS ash reacts with calcium hydroxide generated from the cement hydration process. The amount of pozzolanic material added is limited with the amount of hydroxide produced during the hydration. This was the reason where different percentages of MBS were added to determine the optimum amount in enhancing the compressive strength and water permeability of the concrete. Concrete sample specimens were produced based on the cement percentages replacement of MBS added which were $0 \%, 4 \%, 8 \%$, $12 \%, 16 \%, 20 \%$ and abbreviated with M0, M4, M8, M12, M16 and M20. The mix proportions for concrete mixtures are presented in Table 4. 
Table 4. Mix proportion for concrete mixtures containing various percentages of MBS

\begin{tabular}{ccccccc}
\hline $\begin{array}{c}\text { Mix } \\
\text { Designation }\end{array}$ & $\begin{array}{c}\text { Cement } \\
\left(\mathrm{kg} / \mathrm{m}^{3}\right)\end{array}$ & $\begin{array}{c}\text { MBS } \\
\left(\mathrm{kg} / \mathrm{m}^{3}\right)\end{array}$ & $\begin{array}{c}\text { Water } \\
\left(\mathrm{kg} / \mathrm{m}^{3}\right)\end{array}$ & $\begin{array}{c}\text { Coarse } \\
\text { Aggregate } \\
\left(\mathrm{kg} / \mathrm{m}^{3}\right)\end{array}$ & $\begin{array}{c}\text { Fine } \\
\text { Aggregate } \\
\left(\mathrm{kg} / \mathrm{m}^{3}\right)\end{array}$ & $\begin{array}{c}\mathrm{SP} \\
\left(\mathrm{ml} / \mathrm{kg}^{3}\right)\end{array}$ \\
\hline M0 & 450 & 0 & 225 & 823 & 652 & 4500 \\
M4 & 432 & 18 & 225 & 823 & 652 & 4320 \\
M8 & 414 & 36 & 225 & 823 & 652 & 4140 \\
M12 & 396 & 54 & 225 & 823 & 652 & 3960 \\
M16 & 378 & 72 & 225 & 823 & 652 & 3780 \\
M20 & 360 & 90 & 225 & 823 & 652 & 3600 \\
\hline
\end{tabular}

(Note)

Performances of concrete samples produced were assessed in the fresh and hardened states. In the fresh state, the specimens were tested based on their workability as in Figure 3. The figure indicates that as the amount of MBS increases the workability of the concrete decreases. This is because MBS has high capacity of absorbing water. This is due to cellular characteristic of MBS which lead into high absorption capacity in concrete containing MBS and less water available for workability in the mix. This high absorption characteristic is also found for other pozzolanic material like silica fume (Mazloom et al., 2004) and rice husk ash (Nehdi, 2003; Kartini, 2009).

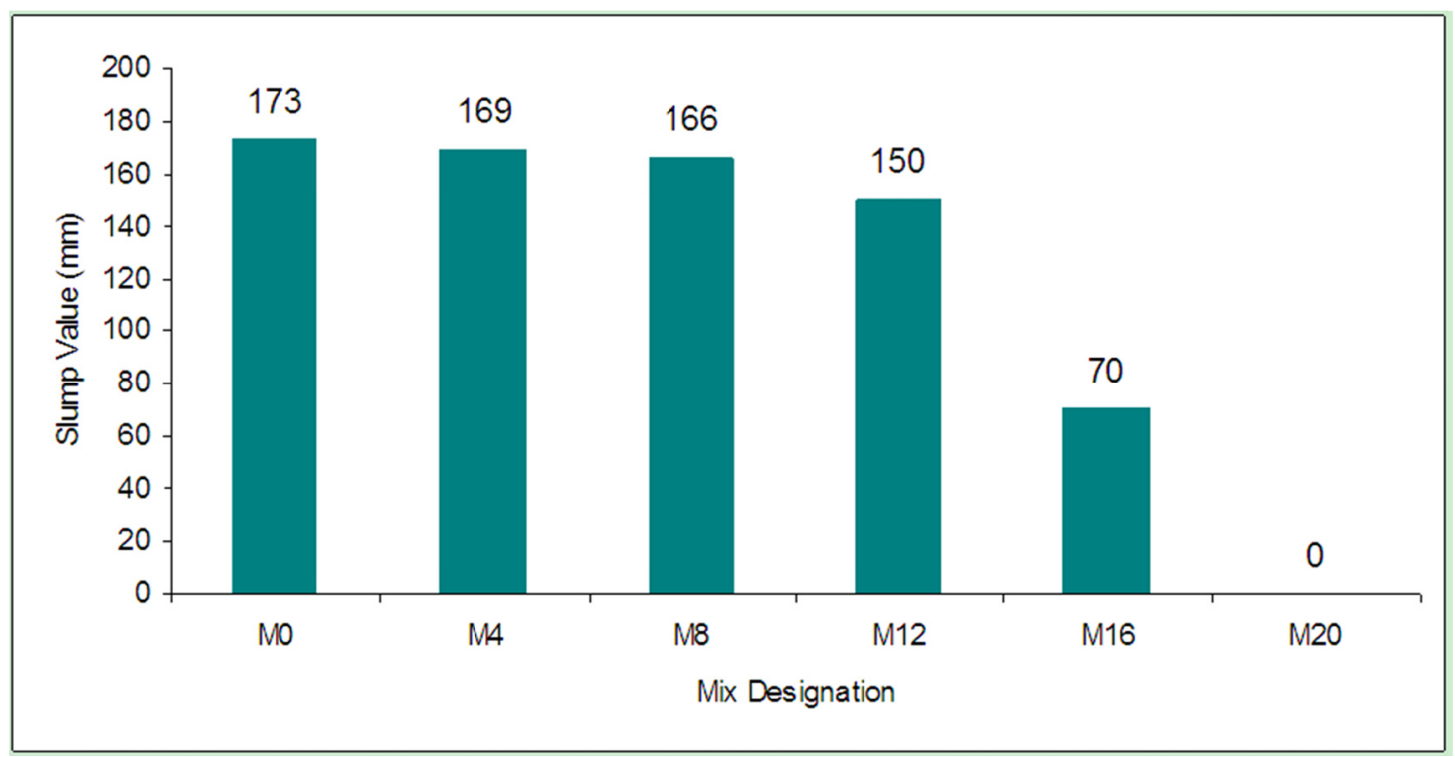

Figure 3. Slump (in $\mathrm{mm}$ ) for concrete mix made of various percentages of MBS content to cement

For hardened concrete samples, the specimens were tested for their compressive strength at the age of $7,14,28$ and 90 days. The results of the compressive strength test are as in Table 5. The table indicates that the optimum percentage of MBS added in concrete is $12 \%$. The highest percentage increased as compared to control concrete is at 90 days, where it accounts for $43 \%$ increased. 
Table 5. Compressive strength for concrete mixes with MBS

\begin{tabular}{cccccc}
\hline \multirow{2}{*}{ Mix Designation } & \multirow{2}{*}{ MBS (\%) } & \multicolumn{4}{c}{ Compressive Strength (MPa) } \\
\cline { 3 - 6 } & & 7 days & 14 days & 28 days & 90 days \\
\hline M0 & 0 & 20.00 & 22.00 & 30.20 & 31.90 \\
M4 & 4 & 24.00 & 28.00 & 32.40 & 35.10 \\
M8 & 8 & 25.00 & 32.10 & 37.50 & 39.60 \\
M12 & 12 & 30.00 & 34.10 & 39.00 & 45.70 \\
M16 & 16 & 18.43 & 25.93 & 27.53 & 28.90 \\
M20 & 20 & 17.20 & 23.33 & 25.53 & 26.80 \\
\hline
\end{tabular}

\section{Performance of Water Permeability}

The durability of concrete is almost directly related to its permeability. Water permeability is the ability of water to flow a pressure differential. In this study, the water permeability for concrete specimens containing various percentages of MBS was measured based on water coefficient. Figure 4 shows the result for water permeability coefficient of concrete samples based on the MBS as pozzolanic material replacing cement. The figure demonstrates that up to $12 \%$ replacement of MBS in the samples had resulted to lower the water coefficient as compared to that of control concrete (M0) specimens. From the overall results, it can be concluded that concrete specimens containing MBS possess better resistance in allowing water to permeate into the concrete as compared to that of control concrete. This is cause from pozzolanic reaction which had taken place between silicon dioxide $\left(\mathrm{SiO}_{2}\right)$ from MBS with calcium hydroxide $\left(\mathrm{Ca}(\mathrm{OH})_{2}\right)$ from cement hydration. The reaction leads into calcium silicate hydrate, C-S-H gel formation. The gel acts to fill up the pores in concrete and also ITZ between aggregate and cement paste. These actions lead to lower permeable characteristic of the concrete.

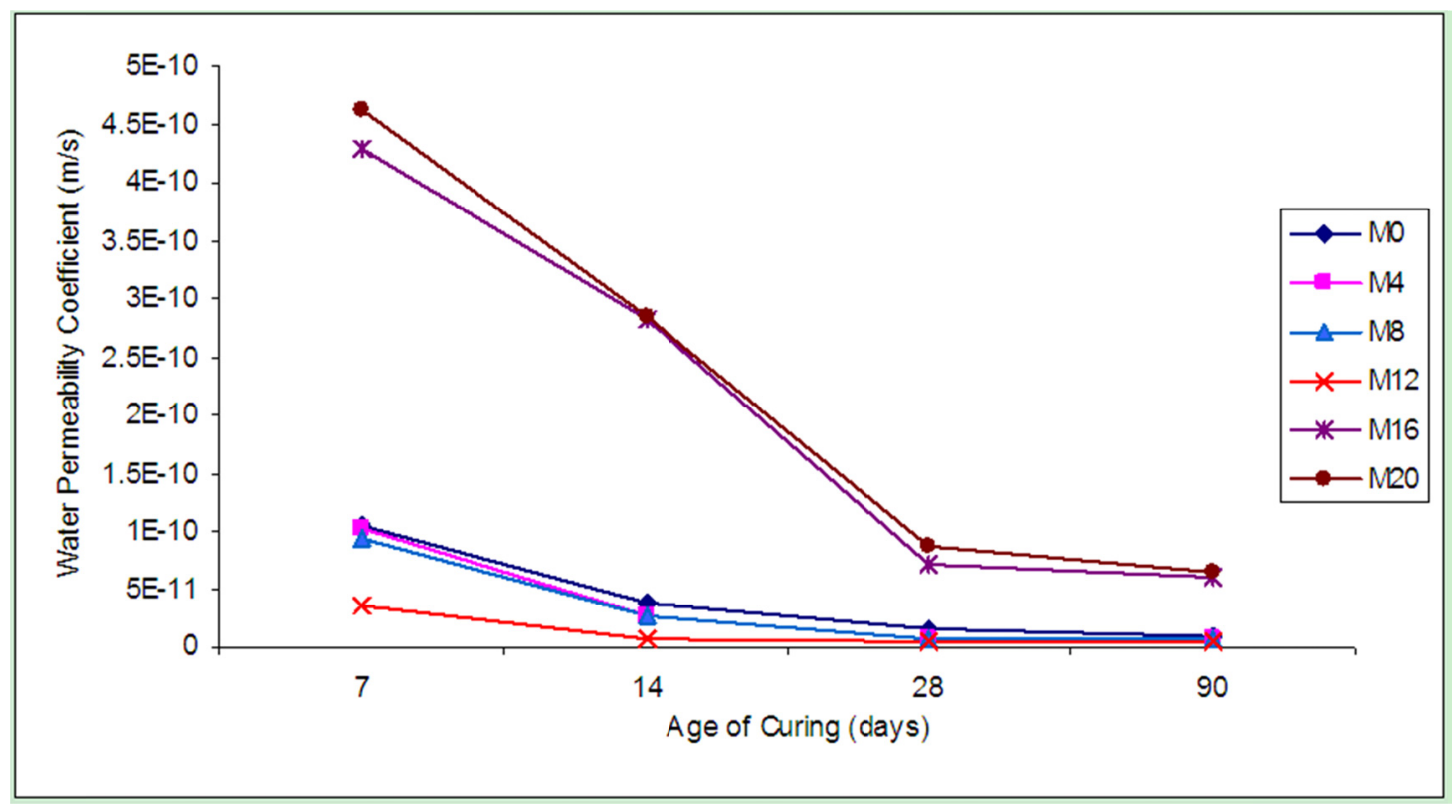

Figure 4. Water permeability coefficient for concrete containing MBS

\section{Effects of Pozzolanicity}

The increasing of concrete compressive strength containing MBS is due to Calcium Hydroxide, $\mathrm{Ca}(\mathrm{OH})_{2}$ which has been produced from the primary cement hydration process reacts with silicon dioxide, $\left(\mathrm{SiO}_{2}\right)$ from MBS (secondary hydration). Primary cement hydration process occurs when tricalcium silicate $\left(\mathrm{C}_{3} \mathrm{~S}\right)$ and dicalcium silicate $\left(\mathrm{C}_{2} \mathrm{~S}\right)$ in cement are hydrated. The hydration process involved is shown in Equation 1. According to Oner et al. (2005), the by-product of primary cement hydration is $70 \% \mathrm{C}-\mathrm{S}-\mathrm{H}$ gel, $20 \% \mathrm{Ca}(\mathrm{OH})_{2}, 7 \%$ 
sulpho-aluminate and 3\% of secondary phases. The calcium hydroxide, $\mathrm{Ca}(\mathrm{OH})_{2}$ from cement hydration process reacts with silicon dioxide $\left(\mathrm{SiO}_{2}\right)$ from MBS which is known as pozzolanic reaction and the reaction process is described as in Equation 2. In this reaction, the calcium hydroxide $\left(\mathrm{Ca}(\mathrm{OH})_{2}\right)$ is transformed into secondary calcium silicate hydrate (C-S-H) gel which leads into transformation of larger pores into finer pores (Oner et al., 2005). This C-S-H gel is able to fill-up to the micro-pores and ITZ in concrete. Thus, this reaction gave a significant effect to the development of concrete strength.

$$
\begin{gathered}
\left(\mathrm{C}_{3} \mathrm{~S}, \mathrm{C}_{2} \mathrm{~S}\right)+\mathrm{H}_{2} \mathrm{O} \rightarrow \mathrm{C}-\mathrm{S}-\mathrm{H}+\mathrm{Ca}(\mathrm{OH})_{2} \\
\text { tricalcium water calcium calcium } \\
\text { silicate and } \quad \text { silica hydroxide } \\
\text { dicalcium silicate } \\
\mathrm{Ca}(\mathrm{OH})_{2}+\mathrm{SiO}_{2} \rightarrow \mathrm{C}-\mathrm{S} \text { - } \mathrm{H} \\
\text { calcium silico calcium silicate } \\
\text { hydroxide dioxide hydrated gel }
\end{gathered}
$$

Finer particles sizes of MBS $\left(24.4039 \mathrm{~m}^{2} / \mathrm{g}\right)$ as compared to cement $\left(2.693 \mathrm{~m}^{2} / \mathrm{g}\right)$ has improved filler mechanism by densifying the cement matrix, filling the voids in concrete with hydration product, improving the bonding with aggregates and reinforced the materials like a glass fiber (Isaia et al., 2003). The physical action of pozzolanic material will contribute into denser, more homogeneous and uniform paste. Thus, it can be seen besides the pozzolanic reaction the filler effect of pozzolan material also plays role in densifying the cement matrix.

MBS possess better resistance in allowing water to permeate into the concrete and also its compressive strength as compared to that of control concrete because of pozzolanic reaction which had taken place between silicon dioxide $\left(\mathrm{SiO}_{2}\right)$ from MBS with calcium hydroxide $\left(\mathrm{Ca}(\mathrm{OH})_{2}\right)$ from cement hydration. The reaction leads into calcium silicate hydrate, C-S-H gel formation. The gel acts to fill up the pores in concrete and also ITZ between aggregate and cement paste. These actions lead to lower permeable characteristic of the concrete.

For samples containing percentage of MBS replacement exceeding the optimum amount, its compressive strength and water permeability will reduce. This is due to the reducing amount of cement content in concrete mixes as the replacement takes higher proportion of cementitious function. It is related to the decreasing amount of C-S-H gel which latter enable to fill up the ITZ and micropores within the matrices in concrete. Consequently, water-filled space is then created and will lower the performance of concrete.

Also, it is evident that MBS does behave like other high pozzolanic reactivity of Supplementary Cementitious Material (SCM) namely silica fume and metakolin as depicted in Table 6. It can be seen from Table 6 that MBS is in agreement with Poon et al. (2006), Wong and Abdul Razak (2005), Mazloom et al. (2004) and Zhang et al. (1996) which shows the enhancement in compressive strength of concrete as SCM was included in the concrete mixes. However, MBS concrete obtained lower compressive strength in 7 and 28 days compared to those of

\begin{tabular}{|c|c|c|c|c|c|c|c|}
\hline \multirow[t]{3}{*}{ Reference } & \multirow{3}{*}{$\begin{array}{c}\text { Type of Supplementary } \\
\text { Cementitious Material } \\
\text { (SCM) }\end{array}$} & \multirow{3}{*}{$\mathrm{w} / \mathrm{c}$ ratio } & \multirow{3}{*}{$\% \mathrm{SCM}$} & \multicolumn{4}{|c|}{ Compressive Strength (MPa) } \\
\hline & & & & \multirow[t]{2}{*}{$\begin{array}{c}7 \\
\text { days }\end{array}$} & \multirow[t]{2}{*}{$\begin{array}{c}28 \\
\text { days }\end{array}$} & \multicolumn{2}{|c|}{$\begin{array}{l}\% \text { difference with } \\
\text { respect to control }\end{array}$} \\
\hline & & & & & & 7 days & 28 days \\
\hline \multirow[t]{4}{*}{ Current Study } & MBS & 0.5 & 0 & 20.0 & 30.2 & 0 & 0 \\
\hline & & & 4 & 24.0 & 32.4 & 20.0 & 7.3 \\
\hline & & & 8 & 24.8 & 37.5 & 24.0 & 24.2 \\
\hline & & & 12 & 29.8 & 39.0 & 49.0 & 29.1 \\
\hline
\end{tabular}
silica fume and metakolin in Poon et al. (2006) study for concrete with same w/c ratio. This is might be due to different strengthening mechanisms of silica fume, metakaolin and MBS in concrete. According to Poon et al. (2006), the different strengthening mechanisms for different SCM have contributed into different development of compressive strength. This is due to pozzolanic reaction which occurred from SCM has becomes as dominant mechanism at early or later age.

Table 6. Findings for various types of Supplementary Cementitious Material (SCM) 


\begin{tabular}{|c|c|c|c|c|c|c|c|}
\hline \multirow{7}{*}{$\begin{array}{l}\text { Poon et al. } \\
\text { (2006) }\end{array}$} & Silica fume & 0.5 & 0 & 41.2 & 52.1 & 0 & 0 \\
\hline & & & 5 & 47.0 & 54.3 & 14.1 & 4.2 \\
\hline & & & 10 & 47.4 & 58.4 & 15.0 & 12.1 \\
\hline & Metakaolin & 0.5 & 0 & 41.2 & 52.1 & 0 & 0 \\
\hline & & & 5 & 45.9 & 57.1 & 11.4 & 9.6 \\
\hline & & & 10 & 55.2 & 66.2 & 34.0 & 27.1 \\
\hline & & & 20 & 43.2 & 58.4 & 4.9 & 12.1 \\
\hline \multirow{8}{*}{$\begin{array}{c}\text { Wong and } \\
\text { Abdul Razak } \\
\text { (2005) }\end{array}$} & Silica fume & 0.3 & 0 & 72.0 & 83.5 & 0 & 0 \\
\hline & & & 5 & 81.0 & 91.0 & 12.5 & 9.0 \\
\hline & & & 10 & 78.5 & 95.0 & 9.0 & 13.8 \\
\hline & & & 15 & 74.5 & 98.5 & 3.5 & 18.0 \\
\hline & Metakaolin & 0.3 & 0 & 72.0 & 83.5 & 0 & 0 \\
\hline & & & 5 & 76.5 & 88.5 & 6.3 & 6.0 \\
\hline & & & 10 & 81.0 & 93.5 & 12.5 & 12.0 \\
\hline & & & 15 & 80.0 & 94.5 & 11.1 & 13.1 \\
\hline \multirow{4}{*}{$\begin{array}{l}\text { Mazloom } \\
\text { al. (2004) }\end{array}$} & Silica Fume & 0.35 & 0 & 46 & 58 & 0 & 0 \\
\hline & & & 6 & 50.5 & 65 & 9.8 & 12.1 \\
\hline & & & 10 & 52 & 67.5 & 13.0 & 16.4 \\
\hline & & & 15 & 53 & 70 & 15.2 & 20.7 \\
\hline \multirow{2}{*}{$\begin{array}{c}\text { Zhang et al. } \\
\text { (1996) }\end{array}$} & Silica fume & 0.3 & 0 & 52.1 & 61.0 & 0 & 0 \\
\hline & & & 10 & 64.8 & 78.9 & 24.4 & 29.3 \\
\hline
\end{tabular}

\section{Conclusions}

This study has indicated the potential benefit of MBS in enhancing the compressive strength and the water permeability of concrete. The pozzolanic properties of MBS satisfy the ASTM C 618-08a standard as pozzolan materials where the proportion of silica, alumina and iron oxide is $88.544 \%$, which is exceeding the standard. It reacts with calcium hydroxide generated from cement hydration has increase the CSH gel to fill up the ITZ and micropores within the matrices in concrete. The significant findings from this study are:

- Workability of fresh concrete decreased with as the content of MBS added to the concrete increased.

- The optimum percentage of MBS added to the concrete that lead to good performance of concrete in terms of compressive strength and water permeability was $12 \%$.

- The compressive strength increased up to $43 \%$ when $12 \%$ of MBS was added to the concrete after 90 days period.

- Increasing the content of MBS exceeding the optimum percentage showed inferior performance of the concrete.

These findings have given good potential in adding values to normal RHA in the application of enhancing the performance of concrete.

\section{Acknowledgements}

Thanks and gratitude to Ministry of Higher Education Malaysia and Research and Innovation Centre of Universiti Tun Hussein Onn Malaysia for the support given in making this study successful.

\section{References}

Awal, A. A. S. M., \& Hussin, M. W. (1997). Effect of Palm Oil Fuel Ash on Durability of Concrete. Fifth International Conference on Concrete Engineering and Technology, 299-306.

Elinwa, A. U., \& Mahmood, Y. A. (2002). Ash From Timber Waste as Cement Replacement Material. Cement and Concrete Composites, 24(2), 219-222. http://dx.doi.org/10.1016/S0958-9465(01)00039-7 
Isaia, G. C., Gastaldini, A. L. G., \& Moraes, R. (2003). Physical and Pozzolanic Action of Mineral Additions on the Mechanical Strength of High Performance Concrete. Cement and Concrete Composites, 25, 69-76. http://dx.doi.org/10.1016/S0958-9465(01)00039-7

Kartini, K. (2009). Mechanical, Time-Dependent and Durability Properties of Grade 30 Rice Husk Ash Concrete. Universiti Malaya: Ph.D. Thesis.

Lee, Y. L., Koh, H. B., Wong, C. K., Suraya, H. A., Suhaizad, S., \& Hung, Y. T. (2007). Micronised Biomass Silica and Nanoparticles Synthesis-Recent Development. Malaysian Construction Research Journal, 1(1), 21-29.

Mazloom, M., Ramezanianpour, A. A., \& Brooks, J. J. (2004). Effect of Silica Fume on Mechanical Properties of High-Strength Concrete. Cement and Concrete Composites, 26, 347-357. http://dx.doi.org/10.1016/S0958-9465(03)00017-9

Nehdi, M., Duquette, J., \& Damatty, A. E. (2003). Performance Of Rice Husk Ash Produced Using A New Technology As A Mineral Admixture In Concrete. Cement and Concrete Research, 33(8), 1203-1210. http://dx.doi.org/10.1016/S0008-8846(03)00038-3

Neville, A. M. (2004). Properties of Concrete. United Kingdom: Pearson Education Limited.

Oner, A., Akyuz, S., \& Yildiz, R. (2005). An Experimental Study on Strength Development of Concrete Containing Fly Ash and Optimum Usage of Fly Ash in Concrete. Cement and Concrete Research, 35, 1165-1171. http://dx.doi.org/10.1016/j.cemconres.2004.09.031

Poon, C. S., Kou, S. C., \& Lam, L. (2006). Compressive Strength, Chloride Diffusivity and Pore Structure of High Performance Metakaolin and Silica Fume Concrete. Construction and Building Materials, 20, 858-865. http://dx.doi.org/10.1016/j.conbuildmat.2005.07.001

Sampaio, J., Coutinho, J. S., \& Sampaiao, M. N. (2000). Portuguese rice husk ash as a partial cement replacement. Proceedings, International Conference: Sustainable Construction into the next Millennium: Environmentally friendly and innovative cement based materials, 125-137.

Toutanji, A. H., \& El-Korochi, T. (1995). The influence of silica fume on the compressive strength of cement paste and mortar. Cement and Concrete Research, 25(7), 1591-1602. http://dx.doi.org/10.1016/0008-8846(95)00152-3

Wong, H. S., \& Abdul Razak, H. (2005). Efficiency of Calcined Kaolin and Silica Fume as Cement Replacement Material for Strength Performance. Cement and Concrete Research, 35, 696-702. http://dx.doi.org/10.1016/j.cemconres.2004.05.051

Zhang, M. H., Lastra, R., \& Malhotra, V. M. (1996). Rice-husk ash paste and concrete: Some aspects of hydration and the microstructure of the interfacial zone between the aggregate and paste. Cement and Concrete Research, 26(6), 963-977. http://dx.doi.org/10.1016/0008-8846(96)00061-0

Note

Note-SP is a superplasticizer. 